\title{
PROVISION OF MARKET INFRASTRUCTURE BASED ON THE SOCIO-CULTURAL CONDITION OF INDONESIAN COMMUNITY
}

\author{
Rozidateno Putri Hanida ${ }^{1}$, Bimbi Irawan $^{2 \star}$, Syamsurizaldi ${ }^{3}$ \\ ${ }^{1}$ Andalas University, Padang, Indonesia, ozidateno@gmail.com \\ 2 BKPM Sumatera Barat Province, Padang, Indonesia, bimbiyes@gmail.com \\ 3 Bappeda Solok Selatan Regency, Padang Aro, Indonesia, s.rizaldi@yahoo.co.id \\ ${ }^{*}$ Corresponding Author
}

\begin{abstract}
Study on the provision of market infrastructure based on the socio-cultural condition of Indonesian community is an attempt to describe the patterns of provision of infrastructure in the market. The provision of the infrastructure must consider the specific characteristic of the people who inhabit in the area. This study was conducted in Solok Selatan Regency. In general, it will not be able to represent the socio-cultural diversity in Indonesia, but in particular it will be able to describe the particularity of socio-cultural Minangkabau community. Markets In Solok Selatan Regency was established by the Nagari Community, a specific traditional government in Minangkabau Ethnic. These markets are generally enlivened once a week, Muara Labuh and Padang Aro Market that they have 2 market days a week. Because almost of all the markets enlivened once a week, the market day always move from one market to the next market. The main components of the implementation of buying and selling process are the merchants and the buyers. Merchants can be classified on the professional, semi-professional, and subsistence merchant. Based on the characteristic of merchants, the major infrastructure that is required in the market is los building. Los building can accommodate all types of merchant. Stall building is also required by a number of market, not all market, that have potential to be develop in future such as the regional and district area market. The second component is the buyer. The buyers come from the population of nagari that be the market service area. However, in the future, to realize the market which fulfilling the aspects of safety, eligibility, and comfortability, providing infrastructure such as parking facilities, police station, fire station, prayer place, water, drainage, water collection and disposal, as well as toilets should also be provided.
\end{abstract}

Keywords: Market, Infrastructure, Socio-Cultural, Local Government.

\section{INTRODUCTION}

Provision of infrastructure in the trade area is part of the policy of development of an area or region in establishing certain functions in order to anticipate the social and economic development in the future. The government should be able to provide an area that can accommodate the trading activities of the population, especially of the middle and the low class. Efforts to revive and restructure the existing traditional markets such that clean look, not seedy is a wise policy. Productive economic activity for the middle and low class people really need to be protected from unfair competition from major activities so that the existence of traditional markets can serve as a platform enables to increase their welfares (Yunus, 2008, p.450). 
In the provision of infrastructure in the market, the government should first pay attention to social and cultural conditions, especially market user. This needs to be known, so that the infrastructure can be identified what the priorities prior to construction. Thus, the infrastructure that is built can be functioned optimally, because it was built according to the needs. The importance of the development of market infrastructure is one of the steps to be taken by the government to realize the market which fulfill the aspects of safety, eligibility, and comfortability. During this time, the traditional market is a market that traditional concept which is generally the traditional market is a market that has the impression of a seedy, less clean and muddy when it rains (Zunaidi, 2013). Markets in Solok Selatan Regency, in general are not also much different from most traditional market conditions in Indonesia. Rundown impression, chaotic, muddy when it rains are general overview of the markets in Solok Selatan Regency.

This paper attempts to examine how the image of social and cultural conditions of Solok Selatan Regency especially the market user. By obtaining an overview of socio-cultural conditions of market users, it will be obtained the infrastructure that must be provided by the government. Provision of infrastructure based on social and cultural conditions is expected to provide an alternative for local governments for the provision of targeted and efficient market infrastructure.

\section{THE PROCESS OF MARKET FORMATION IN MINANGKABAU}

Solok Selatan Regency is located in the southern of West Sumatra Province. People of Solok Selatan Regency is part of a clump of Minangkabau people. Minangkabau has settlement pattern called nagari. The nagari community is formed by at least 4 pieces of the clan.Each clan in the nagari will have a sako and pusako. Sako is a title that is given to the head of the clan. Pusako is land owned by the tribe members both land settlements, agriculture, and the cemetery (Kato, 2005, p.33).Besides the clan, sako, and pusako, nagari should have a complete physical requirement so that an area can be recognized as a nagari(Amir, 1997, p.57-58). The requirements that must be physically possessed nagari are in list on the Table 1.

Table 1: The requirements of physically possessed nagari

\begin{tabular}{|l|l|}
\hline \multicolumn{1}{|c|}{ Physical Requirements } & \multicolumn{1}{c|}{ Mean } \\
\hline - Basasok bajarami & a clear teritorial boundary both natural and artificial boundary \\
\hline - Barumah batanggo & family who live in the household \\
\hline - Balabuh batapian & road and sanitation \\
\hline - Bakorong bakampuang & Settlement \\
\hline - Basawah baladang & agricultural land as economic resource \\
\hline - Bapandam bapakuburan & a burial site \\
\hline - Babalai bamusajik & $\begin{array}{l}\text { A nagari must have at least one customs hall (balai adat) and } \\
\text { one mosque }\end{array}$ \\
\hline
\end{tabular}

In general, nagari in Minangkabau rely on agriculture as forming the structure of the economy. This is in accordance with the requirement of basawah baladang. They sell the agricultural product and buy the need of household in the market. Trading activity for the nagari community was initially implemented near balai adat (customs hall). Balai adat has an open space that is large enough to allow for the merchant to hold merchandise. Because trading activity was carried out near balai adat, some Minangkabau people call Balai for market. Trading activity in the market occured only once a week. Because of once a week, market is also called Pakan. Pakan means week.

Today, not all of the markets in Minangkabau have the market day once a week. Markets in some municipalities in West Sumatera Province such as Bukittinggi, Payakumbuh, and Solok Market have trading activity every day. But, when those markets were established, they were only enlivened once day a week. The activity of the original market day is busier than other days. 
The Minangkabau traditional markets initially was only be implemented in a open space near customs hall (balai adat). Dutch Colonial intervened to arrange market by los building. Over time, traditional markets are not only equipped los building, but began to be equipped with stall building. Now, most of the markets in Minangkabau only have los and stall building and are not equipped by infrastructure that make market become safe, eligible, and comfortable.

\section{PHYSICAL AND SPATIAL CHARACTERISTICS OF MARKETS IN SOLOK SELATAN}

There are 20 markets in Solok Selatan Regency that have grown follow the pattern of settlements (see Figure 1). Population settlement patterns almost forming a linear line follows the pattern of the highway. Markets have grown along a linear path following the pattern of settlement. Markets in Solok Selatan Regency generally is a weekly market, which are enlivened only one day a week. There are only two markets that has two market days a week. Padang Aro was initially also enlivened once a week, every Wednesday. Padang Aro added Saturday as to follow the economic and population growth after it became the capital of Solok Selatan Regency. Muara Labuh initially also had a market day once a week, in Thursday. The growth of population made this market adds the market day on Monday. Muara Labuh served population is greater than Padang Aro. Muara Labuhhas served population 73,212 inhabitants and Padang Arojust has 44,921 inhabitants.

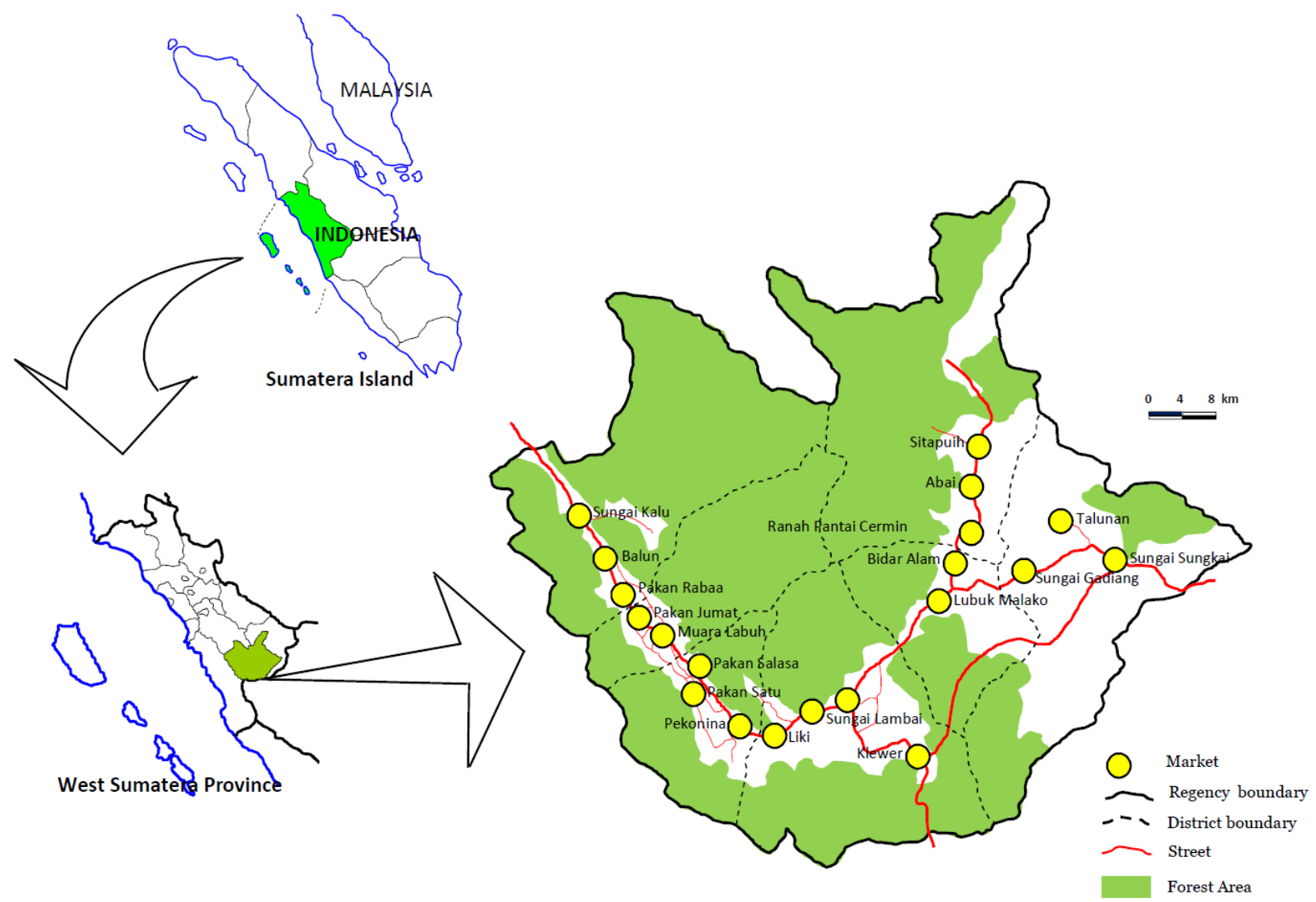

Fig 1: Distribution of markets in Solok Selatan Regency

As a weekly market, market day schedule is made in different days among the adjacent markets. If two adjacent markets have the same market days, there will be a probability to make a market die. Small number of population is a major factor why two adjacent markets have the different market day. From the figure 2 , we can see that the market always move from one market to another. On Monday, there are only two markets in Solok Selatan Regency, Muara Labuh Market in the western and Lubuk Malako Market in the east. Thus every day, both in the west and in the east, the market always move from one place to another place. Naturally, the markets in Solok Selatan Regency will develop into 3 clusters. They are Regional, District, and Nagari market. The member and characteristic of each market cluster in Solok Selatan Regency can be seen in Table 2. 
Regional and district markets have activity a fully day from morning to evening. But Nagari Markets just has trading activity from morning to noon. Regional and district market generally is located in the district or regency capital. These positions make the region as the center from a variety of activities. These areas will not only serve as a buying and selling, but also a gathering place where the community service center in need of goods and services that they cannot produce themselves. In this region a gathering of various service centers, so as to form an agglomeration. Agglomeration provide efficiency especially trips made in fulfilling those needs. Profits from the concentration of activity can be seen economically, geographically, and psychologically. Agglomeration is the distance savings due to reduced travel by nucleation activity (Daldjoeni, 1992, p.99). This is what actually makes regional and district markets tends to be larger than nagari market. 


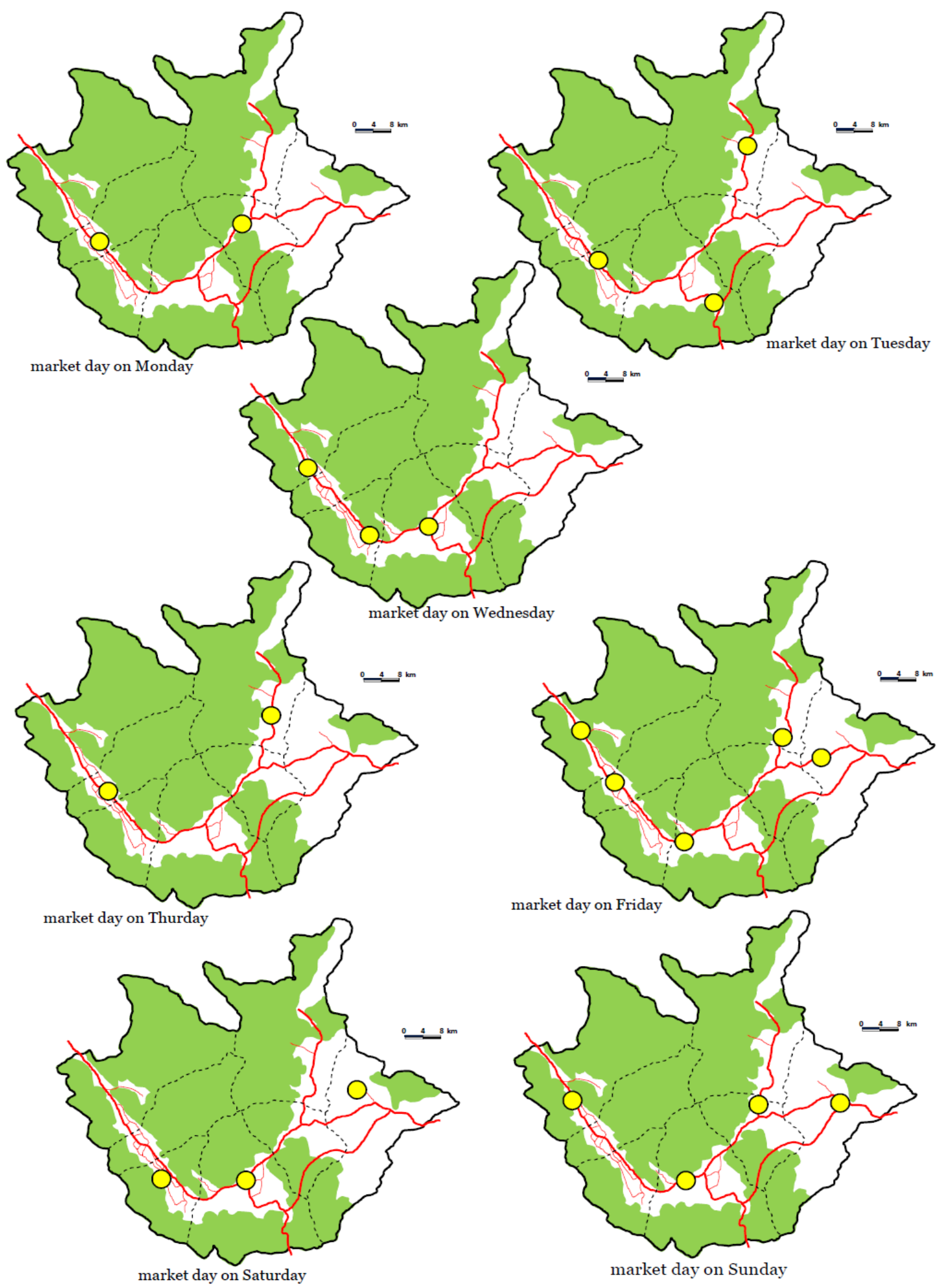

Fig 2: Distribution of market day in a week from Monday to Sunday 
Table 2: Hierarchical Market in Solok Selatan Regency

\begin{tabular}{|c|c|c|}
\hline Market Cluster & Cluster Member & Cluster Characteristics \\
\hline Regional Market & MuaraLabuh, Padang Aro. & $\begin{array}{l}\text { - Serving the population }>30,000 \\
\text { - The served area is more than one district } \\
\text { - Land use is diverse in the area around the market }\end{array}$ \\
\hline District Market & $\begin{array}{l}\text { Sungai Sungkai, PakanRabaa, } \\
\text { Lubuk Malako, Abai, Sungai } \\
\text { Kalu, and Pakan Salasa. }\end{array}$ & $\begin{array}{l}\text { - Serving the population of } 7,000-30,000 \\
\text { - The served area is half of the district } \\
\text { - Generally located at the central of district }\end{array}$ \\
\hline Nagari Market & $\begin{array}{l}\text { Pakan Satu, Sungai Lambai, } \\
\text { Sitapuih, Bidar Alam, Liki, Balai } \\
\text { Akad, Sungai Gadiang, } \\
\text { Talunan, PakanJumat, } \\
\text { Ranah Pantai Cermin, } \\
\text { Pekonina, and Klewer. }\end{array}$ & $\begin{array}{l}\text { - Serving the population of }<7,000 \\
\text { - Serving the population in } 1 \text { or } 2 \text { nagari } \\
\text { - Located far from capital district }\end{array}$ \\
\hline
\end{tabular}

Source: Hierarchy and Traditional Market Development Strategy in Solok Selatan, 2013

Judging from the existing infrastructure in the market, markets generally consists of stall building and los building. These buildings were used merchants to sell their goods. Markets are included in the cluster of the regional market and district market of having both of these buildings, either los or stall. 11 nagari markets do not have stall building. The condition of three nagari markets is worse because they do not have both los and stall building. Traders are forced to set up a tent to hold merchandise. Market physical condition and its market day in Solok Selatan Regency can be seen di Table 3. And what about the other facilities? The market is not equipped with a parking lot so that it make the congestion on the main road. The market is not equipped with a drainage network so that when it rains, the market becomes muddy, and stagnant water here and there. Market physical condition and its market day of

Table 3: Physical condition and distribution of market day in Solok Selatan Regency

\begin{tabular}{|c|c|c|c|c|c|c|c|c|c|c|c|}
\hline \multirow{2}{*}{ Market } & \multirow{2}{*}{$\begin{array}{l}\text { Size } \\
\left(m^{2}\right)\end{array}$} & \multirow{2}{*}{$\begin{array}{l}\text { Number } \\
\text { of Stall }\end{array}$} & \multirow{2}{*}{$\begin{array}{c}\text { Number } \\
\text { of los } \\
\text { building }\end{array}$} & \multirow{2}{*}{$\begin{array}{l}\text { Perking } \\
\text { Area }\end{array}$} & \multicolumn{7}{|c|}{ Market day } \\
\hline & & & & & $\mathbf{M}$ & $\mathbf{T}$ & w & Th & $\mathbf{F}$ & Sa & Su \\
\hline Pakan Rabaa & 3000 & 24 & 3 & Nothing & - & - & $\sqrt{ }$ & - & - & - & - \\
\hline Sungai Kalu & 6700 & 4 & 2 & exist & - & - & - & - & $\sqrt{ }$ & - & - \\
\hline Balai Akad & 2000 & 0 & 2 & Nothing & - & - & - & - & - & - & $\sqrt{ }$ \\
\hline Muara Labuh & 70000 & 128 & 13 & exist & $\sqrt{ }$ & - & - & $\sqrt{ }$ & - & - & - \\
\hline Pakan Jumat & 3000 & 0 & 1 & Nothing & - & - & - & - & $\sqrt{ }$ & - & - \\
\hline Pakan Salasa & 5000 & 2 & 2 & Nothing & - & $\sqrt{ }$ & - & - & - & - & - \\
\hline Pakan Satu & 1200 & 0 & 0 & Nothing & - & - & - & - & - & $\sqrt{ }$ & - \\
\hline Pekonina & 1000 & 0 & 0 & Nothing & - & - & $\sqrt{ }$ & - & - & - & - \\
\hline Padang Aro & 7000 & 64 & 8 & Nothing & - & - & $\sqrt{ }$ & - & - & $\sqrt{ }$ & - \\
\hline Sungai Lambai & 3000 & 0 & 0 & Nothing & - & - & - & - & - & - & $\sqrt{ }$ \\
\hline Liki & 1600 & 0 & 2 & exist & - & - & - & - & $\sqrt{ }$ & - & - \\
\hline Klewer/ TI. Aie Putiah & 1000 & 0 & 0 & Nothing & - & $\sqrt{ }$ & - & - & - & - & - \\
\hline Lubuak Malako & 20000 & 34 & 9 & Nothing & $\sqrt{ }$ & - & - & - & - & - & - \\
\hline Bidar Alam & 3000 & 0 & 3 & Nothing & - & - & - & - & - & - & $\sqrt{ }$ \\
\hline Sungai Sungkai & 3500 & 7 & 4 & Nothing & - & - & - & - & - & - & $\sqrt{ }$ \\
\hline
\end{tabular}




\begin{tabular}{|c|c|c|c|c|c|c|c|c|c|c|c|}
\hline Sungai Gadiang & 2000 & 0 & 5 & Nothing & - & - & - & - & $\sqrt{ }$ & - & - \\
\hline Talunan & 7000 & 0 & 3 & Nothing & - & - & - & - & - & $\sqrt{ }$ & - \\
\hline Abai & 14000 & 20 & 9 & Nothing & - & - & - & $\sqrt{ }$ & - & - & - \\
\hline Sitapuih & 7500 & 1 & 5 & Nothing & - & $\sqrt{ }$ & - & - & - & - & - \\
\hline Ranah Pt. Cermin & 8000 & 0 & 2 & Nothing & - & - & - & - & $\sqrt{ }$ & - & - \\
\hline \multicolumn{5}{|c|}{ Number of market day on the same day } & 2 & 3 & 3 & 2 & 5 & 3 & 4 \\
\hline
\end{tabular}

Source: Hierarchy and Traditional Market Development Strategy in Solok Selatan Regency, Hanida; 2013

Note: $\mathrm{M}=$ Monday, $\mathrm{T}=$ Tuesday, $\mathrm{W}=$ Wednesday, $\mathrm{Th}=$ Thursday, $\mathrm{F}=$ Friday, $\mathrm{Sa}=$ Saturday, $\mathrm{Su}=$ Sunday

\section{CHARACTERISTICS OF MARKET USER IN SOLOK SELATAN REGENCY}

According to its function as a place of purchase, the main components that make up the activity of the market are merchants and buyers. Based on the pattern of goal to get income, the merchants can be classified into four categories. The first is professional merchants, who use trading activities as their main source of income. The second is semi-professional merchants, who conduct trading activities to earn money but income that are from the results of the trade is an additional source. The third is subsistence merchants, who sell the product of the above subsistence activities to fulfill the family economy. In agricultural areas, these merchants are farmers who sell their crops to market. And the last is pseudo merchants, who do trading activities are based as a hobby or for leisure (Damsar, 1997). The last type is not found in Solok Selatan Regency.

Professional and semi-professional merchants must move to follow the market day from one place to another place, so that they require extra costs, especially the cost of transportation. Professional merchants always do trading activity along time. But, the semi-professional merchants do not that. Generally their jobs are the farmers. They will do trading activity in idle time, when there is no activity in the fields.

Muara Labuh and Padang Aro Market are the ultimate choice for professional and semi-professional merchants. There are 617 merchants at Muara Labuh and 563 merchants at Padang Aro. This number indicates the duration of the market and the value of transactions tend to be higher compared with other markets. The next option is district and nagari market. There are many possible movements of merchants to follow the market day. However, the movement of every merchant is not always the same, depending on the strategy developed by each merchant.
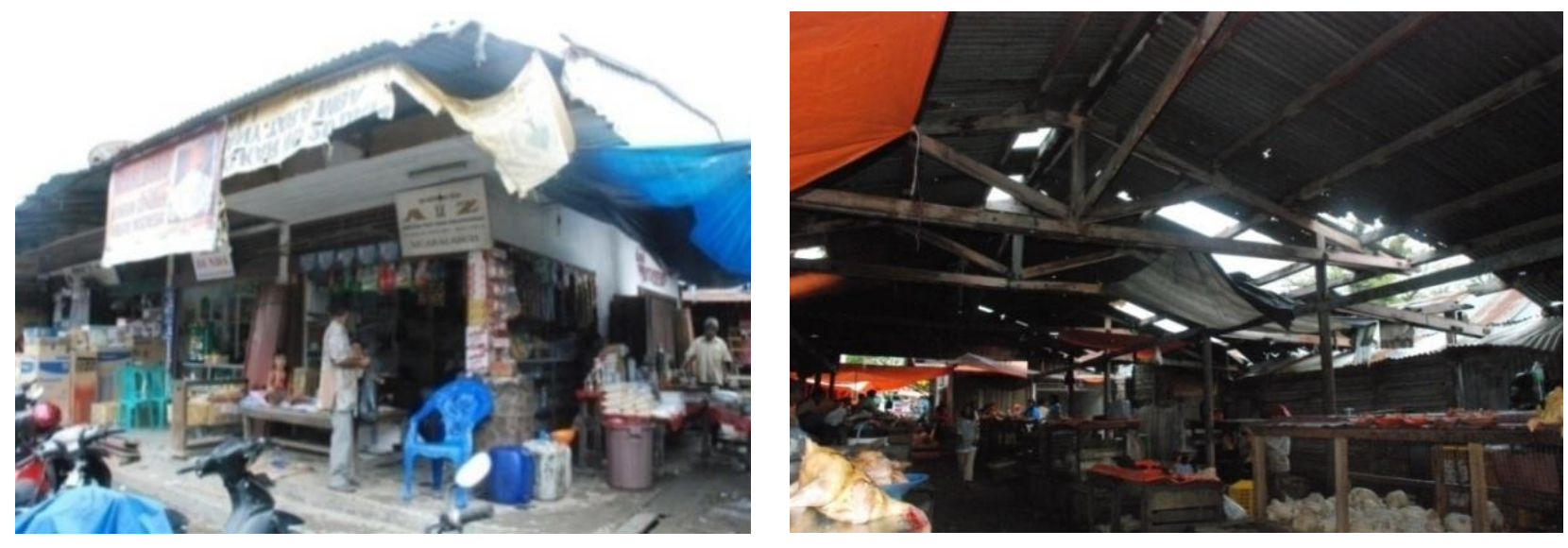

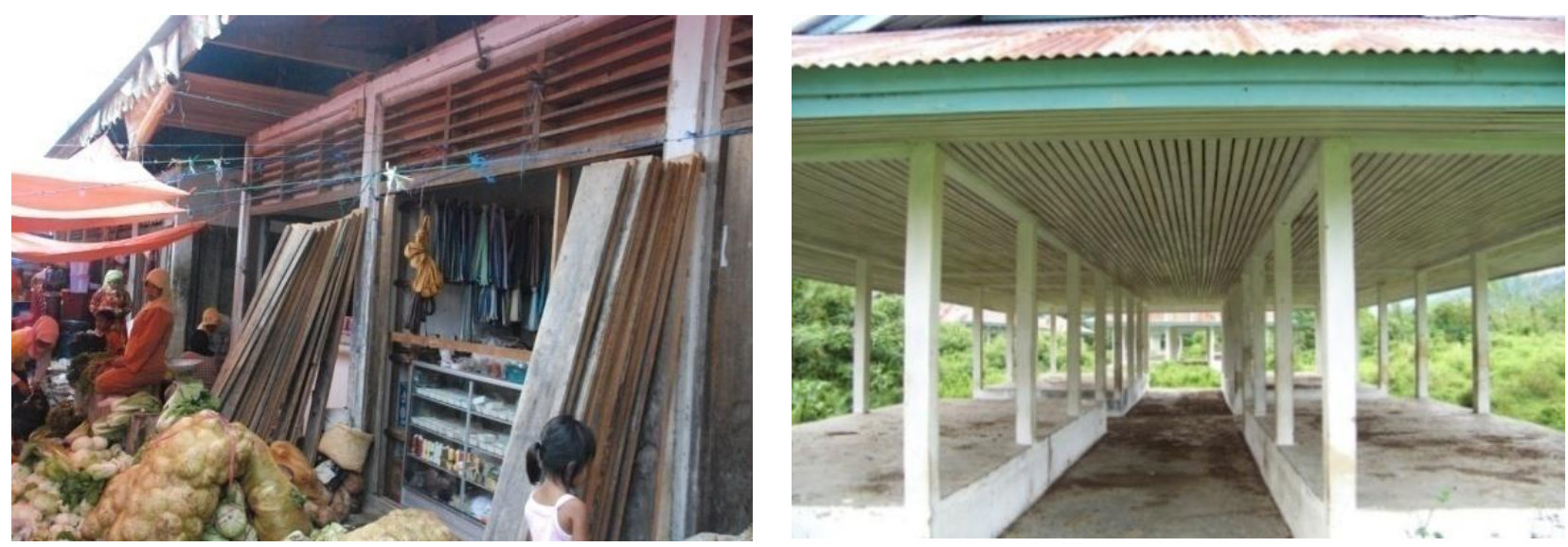

Source: Photo Bimbi Irawan, 2009

Fig 3: The stall building (left) and los building (right)

Professional merchants are usually able to rent a stall in every major market. If not, they can also occupy los building. Or if los building also is full, they become vendors to utilize open spaces. In the stall building, professional merchants can stock up their wares in these markets, thereby reducing the amount of goods carried every market day there. Semi-professional merchants just use los building to sell.
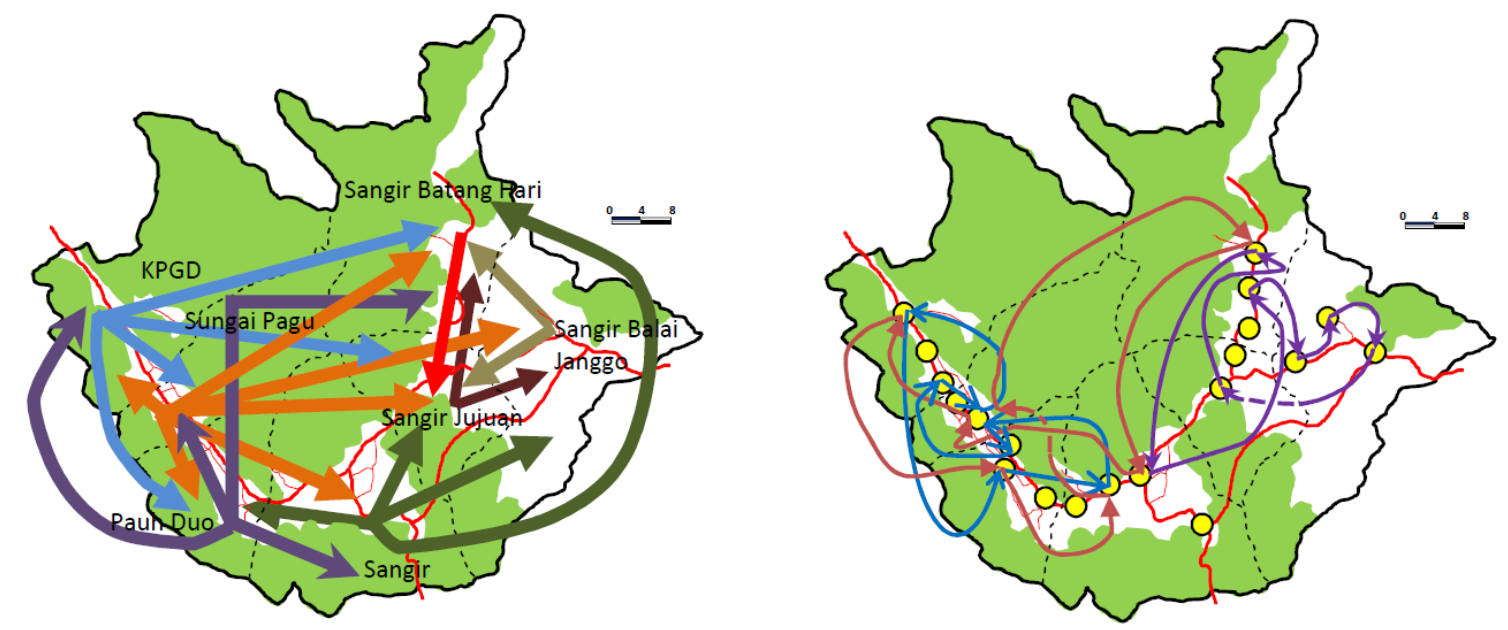

Fig 4: Movement of merchants from their domicile districts (left) and three probability of merchant movements (right)

Based on domicile, merchants who settled in the western part of Solok Selatan Regency have mobility or movement level higher than merchants who settled in the eastern part. Merchants who settled in the western region can be found all of the markets in Solok Selatan Regency. Merchants who settled in Sungai Pagu have the highest level of mobility in Solok Selatan Regency.

The last type of merchants is subsistence merchants. For farmers, the market is a place to directly sell his produce. The advantage gained is they can sell his product in accordance with market prices. Besides farmers, home industry players such as the food industry are also sell their products in the market. The subsistence merchants generally hold merchandise in the open space. If there is an empty in los building, they can hold merchandise in los building. Markets that can be visited are the market that is located close to their settlements. 

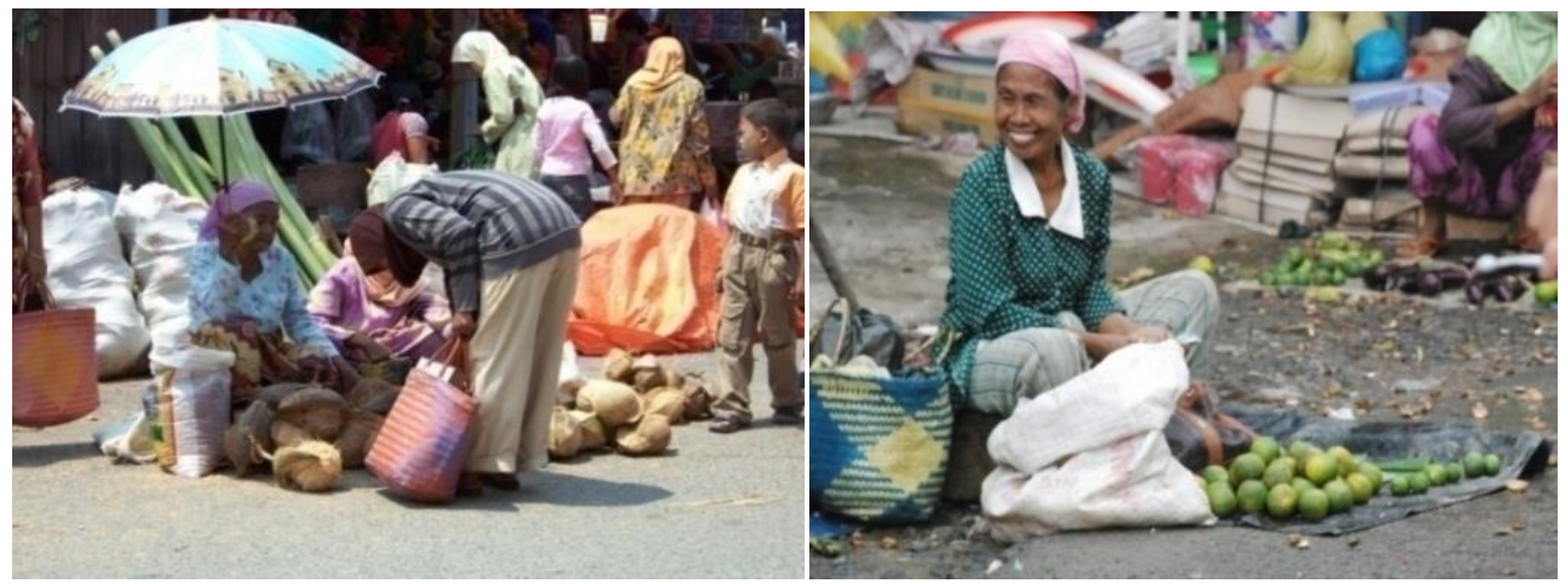

Source: Photo Bimbi Irawan, 2009

Fig 5: Subsistence Merchants

The second important component in market activity is the buyers. Every market has the buyers that come from the nagari resident. They are regular visitors to the market. Besides as a purchase, the traditional markets in Indonesia is also defined as a social and cultural systems (Mukbar, 2007, p.39). Markets in Solok Selatan Regency belongs to nagari and be an asset for Nagari. Although almost all of markets belong to nagari, development of market infrastructures are generally built by the government. This is due to the limited budget that is owned by the nagari.

\section{PROVISION OF MARKET INFRASTRUCTURE}

The main buildings used to trading activity in the markets in Solok Selatan Regency are the stall and los building. The availability of stall and los building still inadequate. In two regional markets in Solok Selatan Regency, the ability of los and stall building to accommodate the merchants in not yet optimal. A half of merchants in all of the markets in Solok Selatan are street vendors. District and nagari markets have the same problem. Most of nagari markets only have los building. Four nagari markets are also not equipped with los building, so that merchants use open area to sell their merchandises.

Overall, the data in 2011 showed that there were 3,575 merchants in 20 markets in Solok Selatan Regency. Capability of stall building to accommodate merchant is low. Stall building just accommodate 213 merchants or $5.96 \%$ of the total merchant. The ability of los building is also too low. Los building just can accommodate 1,296 merchants or $36.25 \%$. The remaining 2,066 merchants or $57.79 \%$ merchants in Solok Selatan Regency are forced to sell in the open space.

Based on this fact, the constructing of los building is a priority that should be done by the Government of Solok Selatan Regency. By placing merchants in los building, it will make the atmosphere of the market becomes more comfortable, more organized, and more orderly.

To realize the market that fulfill the aspects of the safety, eligibility, and comfortability, the building market should be provided not only stall and los building but also other buildings. There is no similar standard of infrastructure required by a market. Refer to the Decree of the Minister of Public Works No. 378/KPTS/1987 dated August 31, 1987, facilities for commercial activities are parking facilities, police station, fire station, post office, and praying place. Other utilities are required such as clean water, sewage drainage, waste collection and disposal and toilets. 
Table 4: The Ability of Markets to Accommodate Merchants

\begin{tabular}{|c|c|c|c|c|c|c|c|c|}
\hline \multirow{3}{*}{$\begin{array}{c}\text { Hierarchy of } \\
\text { Market }\end{array}$} & \multirow{3}{*}{ Market } & \multicolumn{6}{|c|}{ The Merchant Location to Sell } & \multirow{3}{*}{$\begin{array}{c}\text { Total } \\
\text { Merchants }\end{array}$} \\
\hline & & \multicolumn{2}{|c|}{ Stall } & \multicolumn{2}{|c|}{ Los } & \multicolumn{2}{|c|}{ Streetvendor } & \\
\hline & & number & $\%$ & number & $\%$ & number & $\%$ & \\
\hline \multirow[t]{2}{*}{ Regional } & Muara Labuh & 60 & 9,72 & 277 & 44,89 & 280 & 45,38 & 617 \\
\hline & Padang Aro & 64 & 11,37 & 192 & 34,10 & 307 & 54,53 & 563 \\
\hline \multirow[t]{5}{*}{ District } & Lubuak Malako & 34 & 10,24 & 59 & 17,77 & 239 & 71,99 & 332 \\
\hline & Abai & 20 & 8,66 & 146 & 63,20 & 65 & 28,14 & 231 \\
\hline & Sungai Kalu & 4 & 1,56 & 48 & 18,68 & 205 & 79,77 & 257 \\
\hline & Pakan Rabaa & 18 & 7,09 & 72 & 28,35 & 164 & 64,57 & 254 \\
\hline & Sungai Sungkai & 7 & 3,13 & 96 & 42,86 & 121 & 54,02 & 224 \\
\hline \multirow[t]{13}{*}{ Nagari } & Talunan & 0 & 0,00 & 72 & 45,86 & 85 & 54,14 & 157 \\
\hline & Sungai Lambai & 0 & 0,00 & 0 & 0,00 & 117 & 100,00 & 117 \\
\hline & Sungai Gadiang & 0 & 0,00 & 74 & 67,89 & 35 & 32,11 & 109 \\
\hline & Sitapuih & 1 & 0,99 & 60 & 59,41 & 40 & 39,60 & 101 \\
\hline & Pakan Salasa & 5 & 5,95 & 20 & 23,81 & 59 & 70,24 & 84 \\
\hline & Pekonina & 0 & 0,00 & 0 & 0,00 & 80 & 100,00 & 80 \\
\hline & Pakan Satu & 0 & 0,00 & 0 & 0,00 & 78 & 100,00 & 78 \\
\hline & Ranah Pt. Cermin & 0 & 0,00 & 48 & 66,67 & 24 & 33,33 & 72 \\
\hline & Bidar Alam & 0 & 0,00 & 60 & 84,51 & 11 & 15,49 & 71 \\
\hline & Klewer/ T.A. Putiah & 0 & 0,00 & 0 & 0,00 & 62 & 100,00 & 62 \\
\hline & Pakan Jumat & 0 & 0,00 & 24 & 39,34 & 37 & 60,66 & 61 \\
\hline & Balai Akad & 0 & 0,00 & 24 & 45,28 & 29 & 54,72 & 53 \\
\hline & Liki & 0 & 0,00 & 24 & 46,15 & 28 & 53,85 & 52 \\
\hline \multicolumn{2}{|c|}{ Total } & 213 & 5,96 & 1.296 & 36,25 & 2.066 & 57,79 & 3.575 \\
\hline
\end{tabular}

Source: Board of cooperative, trade, and industry of Solok Selatan Regency, 2011

\section{CONCLUSION}

Based on the characteristic of merchants who are in the markets in Solok Selatan Regency, providing los building becomes an important requirement compared to building stall, because market only is used once a week.

The construction of los building in all markets should be a priority for the Government of Solok Selatan Regency. At los building, all merchants can be accommodated on a representative trade place and make it easier to set up merchant who to trade. The construction of stall building must consider the condition and development of market in the future. Only regional markets and district markets need construction of stall building. Besides the provision of stall and los building in most markets, infrastructures to support trade activities such as parking facilities, police station, fire station, places of worship, clean water, sewage drainage, waste collection and disposal as well as latrines or public toilets should be provided. This infrastructure must be provided in order to realize the market that meet the safety standard, eligibility, and comfortability. 


\section{REFERENCE LIST}

Amir MS. (1997). Adat Minangkabau, Pola dan Tujuan Hidup Orang Minang (Minangkabau Culture, Pattern and Goal of Minangkabau People Life). Jakarta. PT. Mutiara Sumber Widya.

Daldjoeni, N. (1992). Geografi Baru, Organisasi Keruangan Dalam Teori dan Praktek (New Geographic, Spatial Organization in Theory and Practice). Bandung: Penerbit Alumni.

Damsar. (1997). Sosiologi Ekonomi (Economic Sosiology). Jakarta: PT. Raja Grafindo Persada.

Kato, T. (2005). Adat Minangkabau dan Merantau dalam Perspektif Sejarah (Minangkabau Culture and Migration in Historical Perspective). Jakarta. Balai Pustaka. p.33

Mukbar, D. (2007). "Denyut Usaha Kecil di Pasar Tradisional Dalam Himpitan Hipermarket (Small Business Pulse in Traditional Market in the Crush of Hypermarkets)". Jurnal Analisis Sosial, 12 (1).

Yunus, Hadi Sabari. (2008). Dinamika Wilayah Peri-Urban Determinan Masa Depan Kota (Dynamics of sub Urban Area Determinant Urban Future). Yogyakarta: Pustaka Pelajar. p. 450.

Zunaidi, Muhammad. (2013). "Kehidupan Sosial Ekonomi Pedagang di Pasar Tradisional Pasca Relokasi dan Pembangunan Pasar Modern (Trader Social and Economic Life in Traditional Market after Relocation and Modern Market Construction)". Jurnal Sosiologi Islam. 3 (1). 